\title{
КООПЕРАЦІЯ ЗАКЛАДІВ ВИЩОЇ ОСВІТИ В УМОВАХ ГЛОБАЛЬНОЇ КОНКУРЕНЦІї
}

\author{
Светлана Бебко
}

\section{КООПЕРАЦИЯ УЧРЕЖДЕНИЙ ВЫСШЕГО ОБРАЗОВАНИЯ В УСЛОВИЯХ ГЛОБАЛЬНОЙ КОНКУРЕНЦИИ}

\author{
Svitlana Bebko

\section{COOPERATION OF HIGHER EDUCATION INSTITUTIONS IN THE CONDITIONS OF GLOBAL COMPETITION}

\begin{abstract}
Глобальні тенденції розвитку торкнулись сфери освіти та науки у більшості краӥнах, тому швидка адаптація до змін та викликів дозволить уникнути впливу модифікованої конкурениї та ускладнень системи взаємозв'язків та взаємозалежностей між учасниками світового ринку науково-освітніх послуг. Стратегія украӥнської освіти та прочеси інтерначіоналізачії спонукають до активізачї̈ нових напрямів розвитку освітньої сфери шляхом кооперачії з закладами інших краӥн і на иій основі подальшу інтеграцію у світовій освітній простір. Кооперативна діяльність в освітній сфері таким чином сприятиме позитивній динаміці національної економіки взагалі й окремих освітніх інституиій. У свою чергу, ие вимагає обгрунтування нових просторових освітньо-наукових парадигмальних засад вивчення відносин між суб'єктами ринку освітніх послуг. Виникає потребу в дослідженні механізмів взаємодії суб 'єктів на ринках освітніх послуг, зокрема кооперації діяльності, шуо спрямовано на підвищення конкурентоспроможності закладів вищуої освіти в умовах глобальної конкуренції. Визначено, щуо кооперація закладів вищої освіти взаємодія двох або більше $3 B O$, серед яких хоча б один є іноземним, форма організації освітньо-наукової діяльності.

Ключові слова: вища освіта; кооперачія; інтернаціоналізачія; конкуренція; конкурентоспроможність; глобалізація.

Рис.: 1. Бібл.: 10 .

Глобальные тенденции развития коснулись сферы образования и науки в большинстве стран, поэтому быстрая адаптаиия к изменениям и вызовам позволит избежать влияния модифииированной конкурениии и осложнений системы взаимосвязей и взаимозависимостей между участниками мирового рынка научно-образовательных услуг. Стратегия украинского образования и прочессы интернационализачии побуждают к активизации новых направлений развития образовательной сферы путем кооперачии с учреждениями других стран и на этой основе дальнейшей интеграции в мировое образовательное пространство. Кооперативная деятельность в сфере образования может способствовать положительной динамике начиональной экономики вообше и отдельных образовательных учреждений в частности. В свою очередь, это требует обоснования новых пространственных образовательнонаучных парадигмальных основ изучения отночений между субъектами рынка образовательных услуг. Возникает потребность в исследовании механизмов взаимодействия субъектов на рынках образовательных услуг, в частности кооперации совместной деятельности, целью которой является повышение конкурентоспособности высших учебных заведений в условиях глобальной конкурениии. Определено, что кооперачия высших учебных заведений - взаимодействие двух или более учреждений образования, среди которых хотя бы один является иностранным партнером, форма организации образовательно-научной деятельности.
\end{abstract}

Ключевые слова: высиее образование; кооперачия; интерначионализаиия; конкурениия; конкурентоспособность; глобализация.

Рис.: 1. Библ.: 10.

Global development trends have affected education and science in most countries, so rapid adaptation to change and challenges will avoid the impact of modified competition and the complexity of the system of relationships and interdependencies between participants in the global market for research and education services. The strategy of Ukrainian education and the processes of internationalization encourage the activation of new directions of development of the educational sphere through cooperation with institutions of other countries and on this basis further integration into the world educational space. Cooperative activities in the field of education will thus contribute to the positive dynamics of the national economy in general and individual educational institutions. In turn, this requires substantiation of new spatial educational and scientific paradigmatic principles of studying the relations between the subjects of the market of educational services. There is a need to study the mechanisms of interaction of entities in the markets of educational services, in particular the cooperation of activities aimed at increasing the competitiveness of higher education institutions in the face of global competition. It is determined that the cooperation of higher education institutions is the interaction of two or more higher education institutions, at least one of which is foreign, a form of organization of educational and scientific activities.

Keywords: higher education; cooperation; internationalization; competition; competitiveness; globalization.

Fig.: 1.References: 10.

JEL Classification: I23

() Бебко С. В., 2020 
Постановка проблеми. Глобалізація підтвердила те, що сучасний світ - це єдине ціле, а окремі національні утворення як його елементи, мають ознаки взаємопов'язаності, взаємозалежності та інтегральності. Соціально-економічні, політичні процеси, які відбуваються в останні роки, вплинули на всі країни та продукували як позитивні зміни, так і мають негативні наслідки для суспільства.

Глобальні тенденції розвитку також торкнулись сфери освіти та науки в більшості країнах, тому швидка адаптація до змін та викликів дозволить уникнути впливу модифікованої конкуренції та ускладнень системи взаємозв'язків та взаємозалежностей між учасниками світового ринку науково-освітніх послуг.

Сьогодні світові ринки освітньо-наукових послуг $є$ доволі динамічними та прогресуючими, їхня ємність оцінюється в розмірі понад 100 млрд дол. Уряди іноземних країн визнають міжнародну освіту ключовим чинником у створенні нових робочих місць у країні перебування іноземних здобувачів вищої освіти, оскільки активізується попит та споживання через зростання кількості осіб у країні навчання, що продукуватиме мультиплікативні ефекти. Відповідно українські заклади вищої освіти мають потенціал для навчання та наукової діяльності для осіб з інших країн.

Стратегічні орієнтири української освіти орієнтовані на зростання престижу України шляхом виходу на міжнародні освітні ринки, збільшення кількості іноземних здобувачів вищої освіти, нарощування потенціалу українських студентів, інституційну автономію ЗВО, професійний розвиток науково-педагогічного персоналу.

Стратегія української освіти та процеси інтернаціоналізації спонукають до активізації нових напрямків розвитку освітньої сфери шляхом кооперації із закладами інших країн і на цій основі подальшу інтеграцію у світовій освітній простір. Кооперативна діяльність в освітній сфері таким чином сприятиме позитивній динаміці національної економіки взагалі й окремих освітніх інституцій. У свою чергу, це вимагає обгрунтування нових просторових освітньо-наукових парадигмальних засад вивчення відносин між суб'єктами ринку освітніх послуг.

Аналіз останніх досліджень і публікацій. Світова та вітчизняна наука має значний доробок з питань розвитку освіти, зокрема 3 питань інтернаціоналізації, міжнародної освіти, участі та ролі груп стейкхолдерів у процесах освітньої діяльності.

Наукові дослідження у сфері інтернаціоналізації освіти, розвитку нових форм співпраці у освітньому середовищі як на національному, так і на міжнародному рівнях $є$ цариною наукових інтересів багатьох як закордонних, так і вітчизняних авторів.

Як провідна тенденція сучасного розвитку, глобалізація докорінно змінює зовнішнє середовище діяльності освітніх закладів, яким притаманні висока невизначеність, загальна взаємна зв'язність і гостра конкуренція. Існуюча сфера освіти в Україні не відповідає сучасним потребам суспільства, особистості, і це підкреслює необхідність зміни цієї ситуації. Основою розпочатої трансформації стає глобалізація, яка через модернізацію системи освіти повинна змінити уявлення суспільства про цю систему, орієнтуючи ії на побудову суспільства знань, основою якого має стати висококласний людський капітал, сформований системою освіти, яка модифікується згідно зі світовими вимогами. На цій тезі акцентує свої дослідження щодо впливу глобалізації на сектор освіти І. Силадій [8].

Сьогодні освіта перетворюється на тривалий і безперервний процес з якісними та кількісними змінами. Ці зміни, характерні для самого процесу освіти, відбуваються на фоні глобальних процесів, що охоплюють економіку окремих країн, регіонів і світу загалом. Саме освіта призводить до нарощування людського потенціалу та його системної капіталізації, виступає драйвером розвитку особистості. Цей вектор досліджень становить науковий інтерес Ж. Дерій [2; 3]. 
ТЕОРЕТИЧНІ ПРОБЛЕМИ РОЗВИТКУ НАЦІОНАЛЬНОЇ ЕКОНОМІКИ

Значний науковий доробок у вивченні теоретико-методологічних засад модернізації системи вищої освіти на основі дослідження впливу на її розвиток інформаційної економіки і тенденцій трансформації глобального науково-освітнього простору має Н. Холявко. Учена визначила стратегічні детермінанти модернізації системи вищої освіти в контексті формування інформаційної економіки, також нею запропоновано стратегію взаємодії системи вищої освіти та підприємництва на основі впровадження інтегрованої моделі фінансування Quadruple Helix [10].

Дослідженню питань досвіду країн у питаннях міжнародної освіти та розвитку ринків міжнародних освітніх послуг присвячено роботи А. Вербицької. У своїх працях авторка констатує, що виправданою та актуальною є стійка тенденція до інтернаціоналізації вищої освіти та іiі інтеграції в глобальний простір. Міжнародний ринок освітніх послуг характеризується зростанням конкуренції: поряд із традиційними лідерами ряд країн розвиває активну політику щодо просування власного освітнього продукту [1].

Питання міжвузівського співробітництва досліджували багато науковців, зокрема С. Захарін та Д. Коваленко вивчають питання україно-китайської співпраці в частині освітньої діяльності, зважаючи на наявність взаємного інтересу представників академічної спільноти країн до реалізації спільних проєктів [4].

Одним із напрямів досліджень щодо освіти є вивчення питань кооперації на ринку освітніх послуг. Конкуренція у сфері освіти знаходиться під безпосереднім впливом конкуренції на ринку праці: роботодавці бажають отримати кращих працівників, освітні заклади при цьому конкурують за їх підготовку. Однак при цьому закладаються основи деформації партнерства, виникає система нерівноправних відносин.

На думку О. Кузьміна, сучасні тенденції розвитку вищої школи, наявний стан системи вищої освіти в Україні спонукає до пошуку перспективних шляхів розвитку, які дозволять закладам вищої освіти насамперед виконувати покладену на них місію i, як наслідок, посісти достойне місце на ринку освітніх послуг. Якщо керуватись твердженням, що сучасним університетам відведена провідна роль в адаптації до глобалізації, то зрозумілою і логічною є доцільність вибору курсу на розширення міжнародної співпраці [5].

Тому, незважаючи на широкий пласт наробок з питань розвитку освіти, нині виникає потреба в дослідженнях, які б містили системний підхід до аналізу нових форм внутрішньосекторальної взаємодії, зокрема кооперації, що $є$ актуальним за умов глобальної конкуренції на світових ринках, зокрема й на ринку надання освітніх послуг.

Виділення недосліджених частин загальної проблеми. Зважаючи на особливу актуальність проблеми, пов'язаної з розвитком інтернаціоналізації освіти, що посилюється процесами активізації на міжнародних ринках освітніх послуг, глобалізації та інтеграції національних економік у єдиний економічний простір, виникає необхідність у дослідженні напрямів співпраці у сфері вищої освіти, зокрема кооперації.

Мета статті. Головною метою статті є дослідження механізмів взаємодії суб'єктів на ринках освітніх послуг, зокрема кооперації діяльності, що спрямовано на підвищення конкурентоспроможності закладів вищої освіти в умовах глобальної конкуренції.

Виклад основного матеріалу. Четверта промислова революція, яка будується на інформаційних технологіях третьої революції, характеризується поєднанням процесів, які усувають межі між фізичною, цифровою та біологічною сферами. Швидкість змін, що відбуваються в соціально-економічних системах, $є$ безпрецедентною, їхні масштаби охоплюють трансформацію системи виробництва та управління без винятку в усіх секторах економіки, при цьому всі процеси здійснюються експоненційно, а не лінійно.

У людства з'явились необмежені можливості щодо отримання знань та інформації завдяки мобільним засобам високої обчислювальної здатності та ємності пам'яті. Ці можливості будуть зростати кумулятивно за рахунок нових освітніх напрямів - штуч- 
ний інтелект, нанотехнології, біотехнології, квантові обчислення та ін. Завдяки отриманим знанням виникають потенційні перспективи щодо зростання глобального рівня доходів, поліпшення якості життя населення. Проте виникає пересторога - інформаційна революція може призвести до поглиблення нерівності, що особливо відобразиться на ринках праці. Ринки праці будуть структуруватись за сегментами: низькокваліфікований/низькооплачуваний; висококваліфікований/високооплачуваний.

Бенефіціарами інновацій $є$ постачальники інтелектуального капіталу, які формують пропозицію висококваліфікованої праці на ринку праці, відповідно попит на працівників 3 неякісною освітою та кваліфікацією знижується. Така ситуація породжує логічне запитання - а чи здатні сучасні заклади освіти підготувати висококваліфікованого фахівця, 3 достатнім рівнем «hard skills» та «soft skills»? У такому напрямі здійснюються сучасні трансформаційні зрушення в системі освіти, науки та інформаційних технологій.

Можемо стверджувати, що на конкурентних ринках освітніх послуг перевагу має той, хто швидше і краще продає свої послуги та розробки. Для ефективної комерціалізації потрібні відповідним чином створені структури, які функціонують як система. В Україні ключові стейкхолдери освітньої діяльності не лише мають низький розвиток, але і проблему взаємодії між собою та із зовнішнім середовищем.

Сучасна пропозиція послуг на ринку освіти формується під впливом факторів, як то:

- нові технології надання освітніх послуг, які продукують нові способи задоволення освітніх потреб;

- гнучкість та інноваційність конкурентів, які здатні витіснити традиційних надавачів освітніх послуг за рахунок високої якості та конкурентної ціни;

- зміна попиту на освітні послуги та нові моделі поведінки споживача таких послуг;

- розвиток освітніх платформ, які через високий рівень інформатизації створюють нові способи споживання послуг освіти;

- зниження бар'єрів в отриманні освітніх послуг, змінюючи при цьому особисте та професійне середовище.

Названі фактори одночасно є інноваційними чинниками розвитку сфери освіти. Проте, крім можливостей, сучасний світ формує соціально-економічні асиметрії, які проявляються в обмежених можливостях отримати освіту. Такі асиметрії проявляються і певних типах нерівностей:

- економічна нерівність, яка пов'язана з різними доходами як різних соціальних груп, так і між особистостями;

- структурна нерівність $є$ висхідною умовою процесів розподілу, вона проявляється в нерівному розподілі можливостей;

- представницька нерівність.

Соціально-економічні умови, політика країн у галузі освіти, глобалізаційні тенденції приводять до виникнення нових форм співпраці та пошуку нових взаємодій між закладами освіти різних країн. Так підписання Угоди Україна-СС, відповідні євроінтеграційні реформи, які здійснюються в багатьох сферах життя суспільства, зокрема й у сфері освіти та науки, відкривають «вікно можливостей» перед університетами та науковими установами. Але спрямованість на якісний результат, ефективність системи вищої освіти вимагає широких партнерських відносин з усіма соціальними, політичним та економічними інституціями як у країні, так й за ії межами. Така співпраця та партнерство мають за мету підтримку та розвиток міжнародної діяльності, інтернаціоналізацію діяльності, входження до світової освітньої та наукової спільноти. Також на користь міжнародної співпраці говорить те, що сучасні заклади освіти виконують провідну роль в адаптації до глобалізації, є центрами зосередження інтелектуального капіталу, здатні продукувати нові знання, створювати продукт із високою доданою вартістю. 
ТЕОРЕТИЧНІ ПРОБЛЕМИ РОЗВИТКУ НАЦІОНАЛЬНОЇ ЕКОНОМІКИ

Однією з форм міжнародної співпраці закладів освіти різних країн можна назвати кооперацію, діяльність, яка в умовах глобальної конкуренції та боротьби за споживача освітніх послуг має свої переваги та дозволить освітнім закладам посісти своє місце на ринку освітніх послуг. На нашу думку, кооперація закладів вищої освіти - взаємодія двох або більше ЗВО, серед яких хоча б один $є$ іноземним, форма організації освітньонаукової діяльності зі спільного досягнення загальних цілей та задоволення потреб учасників об'єднання.

За офіційною інформацією Міністерства освіти і науки України, для українських закладів освіти є певні передумови входження в кооперацію з іноземними закладами освіти. Зокрема, одним із основних пріоритетів національної політики у сфері освіти та науки $\epsilon$ інтеграція України до Європейського дослідницького простору. Цьому сприяє двостороння міжнародна співпраця з країнами-членами $\mathrm{CC}$, з країнами східного партнерства, участь у Рамковій програмі СС з досліджень та інновацій «Горизонт 2020». Починаючи 3 2014 року українські учасники отримали 182 гранти на суму 31830000 євро.

Вітчизняні університети та наукові установи беруть активну участь у двосторонньому науково-технічному співробітництві в межах міжурядових угод. Так, 2019 року українські вчені виконували 119 білатеральних проєктів спільно з науковцями 312 країн: більша половина - це члени СС, а також Індія, Китай, США, Білорусь, Корея. Порівняно з 2018 роком, кількість двосторонніх проєктів зросла майже на чверть.

Також Україна бере асоційовану участь у Програмі наукових досліджень та навчання «Свратом», Міжнародній європейській інноваційній науково-технічній програмі «EUREKA», програмі НATO «Наука заради миру» тощо. Українські дослідницькі організації і університети співпрацюють 3 міжнародними організаціями та фондами, серед яких Свропейська організація 3 ядерних досліджень, Український науковотехнологічний центр, Науковий комітет з антарктичних досліджень [6].

Навіть євроінтеграційні процеси у сфері освіти і науки не є однозначними для вітчизняних закладів освіти, оскільки, з одного боку, створюють нові можливості через участь у європейських освітніх та науково-технологічних програмах, а з іншого боку, посилюють фактори впливу глобальної конкуренції, яка проявляється також у збільшенні кількості українських здобувачів вищої освіти, які вибрали для навчання закордонні університети, та в еміграції науковців [7]. Тому кооперація з іноземними партнерами дозволить зменшити негативний вплив факторів зовнішнього середовища та конкуренції на національну систему освіти.

Опрацювання світового досвіду у сфері співпраці закладів освіти різних країн показує, що передумовами такої співпраці, і зокрема кооперації є: соціально-економічні; правові; політичні; психологічні.

Можемо стверджувати, що в Україні вже сформовано інституційні передумови кооперації з іноземними закладами освіти. Такими передумовами $є$ підписання Болонської декларації у 2005 р., яка передбачає стандартизацію підходів у навчанні та функціонуванні й розвитку вищої освіти.

Крім того, хоча й не надто активно, розвивається експорт освітніх послуг та навчання іноземних студентів, у тому числі дистанційне навчання засобами інтернеттехнологій, що стало актуальним в умовах пандемії, викликаної COVID-19, розвивається транснаціональна освіта.

Так, за даними Українського державного центру міжнародної освіти, постійно зростає попит на отримання освіти в Україні іноземними громадянами (рис. 1). 
ТЕОРЕТИЧНІ ПРОБЛЕМИ РОЗВИТКУ НАЦІОНАЛЬНОЇ ЕКОНОМІКИ

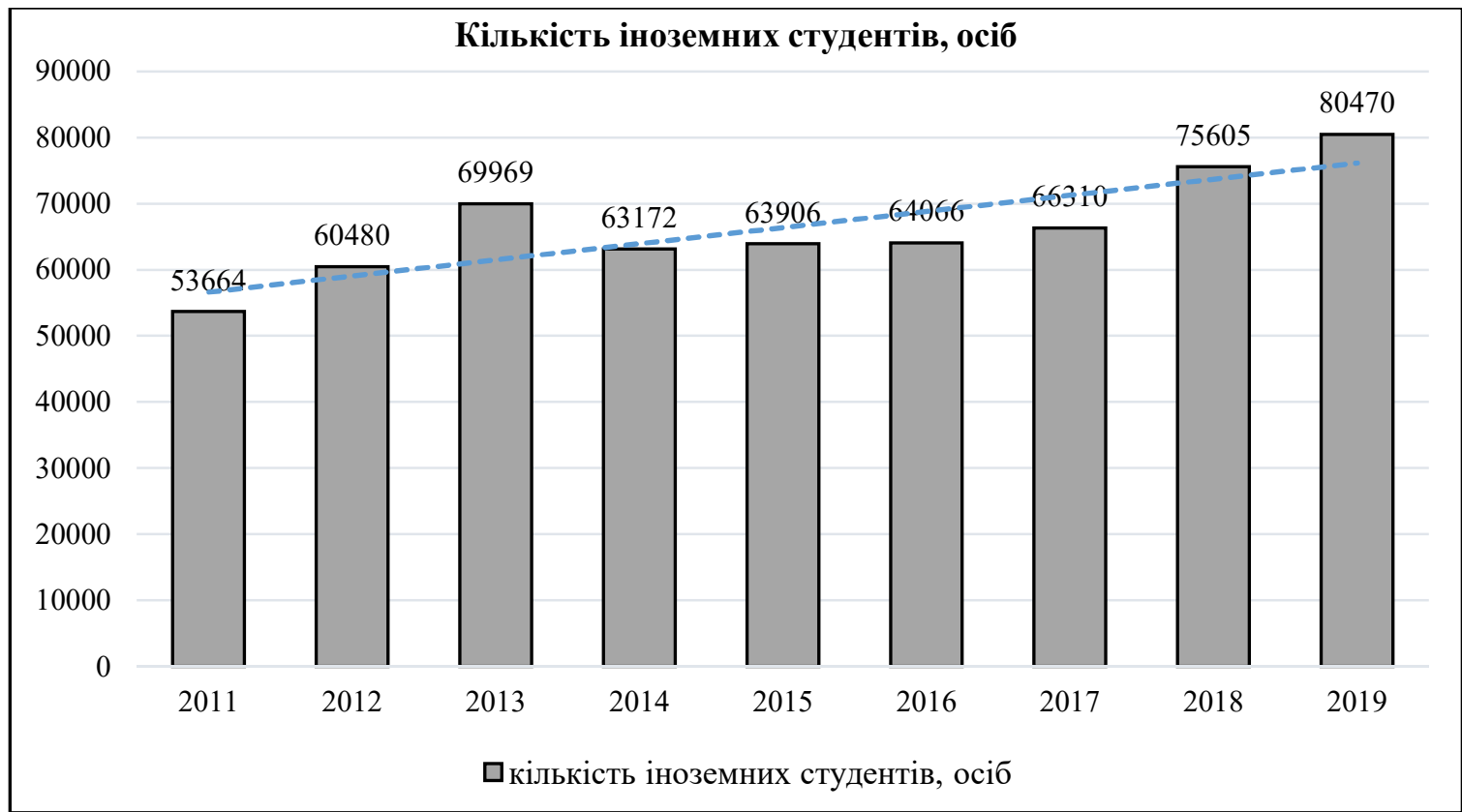

Рис. 1. Іноземні здобувачі вищої освіти, які навчаються в Україні

Джерело: складено за даними [7].

Структурний зріз показує, що 87,5 \% іноземних громадян приїжджають на навчання, 8,64 \% для мовної підготовки. 3 метою післядипломної освіти в Україні перебуває 3,5 \% усіх іноземних громадян, які в’їхали в країну отримувати освітні послуги, та лише 0,01% прибули в країну за програмою академічної мобільності.

На жаль, сьогодні існують організаційні та правові проблеми розвитку експорту освіти внаслідок того, що в Україні діє складна та забюрократизована система первинного запрошення іноземного студента на навчання, мережа закордонних рекрутаційних центрів українських 3ВО нерозвинена [9].

Потребує вирішення питання зарахування до ЗВО іноземних громадян з урахуванням їхніх навчальних досягнень, які вони здобули, навчаючись за кордоном. Проблемою залишається підтвердження українських дипломів за кордоном, існують труднощі в оплаті праці іноземних викладачів, що звужує можливості їх залучення до навчального процесу в Україні.

Міжнародна конкуренція внаслідок того, що міжнародний ринок вищої освіти $є$ доволі прибутковим, висуває вимоги до якості підготовки фахівців та запровадження сучасних форм навчання, при цьому акцент варто робити на науковій компоненті освітньої діяльності, яка повинна стати основою навчального процесу в університеті.

Кооперація у сфері освіти дозволить українським 3ВО долучатись до обміну світовими освітніми та науковими розробками, методиками викладання, технологією дистанційного викладання, проводити дослідницьку роботу та ін.

Можемо стверджувати, що мета кооперації 3 ВО - сприяти модернізації освітнього середовища в умовах глобалізації шляхом включення в освітній процес навчальних закладів різних країн, які утворивши дієздатну структуру можуть конкурувати на світовому ринку та продукувати якісні та інноваційні освітньо-наукові послуги за рахунок ефекту масштабу.

Концептуально кооперація повинна базуватись на принципах, які в подальшому стають основою при формуванні задач та напрямів діяльності суб'єктів, які входять в об'єднання. Основними принципами для кооперації у сфері освіти можна назвати наступні: добровільності та відкритого членства; участь учасників у розробці політик та прийнятті рішень; участь учасників в економічній діяльності; участь учасників у освіт- 
ТЕОРЕТИЧНІ ПРОБЛЕМИ РОЗВИТКУ НАЦІОНАЛЬНОЇ ЕКОНОМІКИ

ньо-науковій діяльності; автономія та незалежність учасників; розвиток та удосконалення структури; співпраця з органами влади та установами які не входять до кооперативу; розвиток на засадах сталості.

Завдяки кооперації ЗВО на цьому етапі суспільного розвитку можуть відбуватись такі види співпраці та взаємодій: обмін викладацькими кадрами; участь у міжнародних освітніх проєктах; міжнародна акредитація освітніх програм; академічна мобільність студентів; програми подвійних дипломів; спільні наукові публікації; міжнародні конференції; проведення спільних наукових досліджень; розвиток мережі міжнародних центрів; проведення гостьових лекцій; розвиток startup руху; дистанційне навчання.

На жаль, сьогодні кооперація закладів освіти відбувається не надто активно, існують перешкоди, які потрібно усувати найближчим часом, проте очевидними є вигоди від кооперації для суб'єктів кооперації як вітчизняних, так і закордонних.

Така вигода базується на динамічному ефекті зростаючого масштабу завдяки розширенню ринку та економії на масштабах виробництва. При цьому забезпечується достатній рівень конкуренції, відбувається зміна економічної ефективності при зростанні масштабів надання освітніх послуг. Зростаючий характер масштабу виробництва включає в себе нарощування обсягів надання різноманітних освітніх послуг, розширення їх переліку, збільшення можливостей для модернізації діяльності.

Кооперація також продукує вигоди для різних учасників ринку освітніх послуг. Так, для ЗВО з'являються можливості щодо розширення контактів у сфері спільного виконання науково-дослідних проєктів, адаптація світового досвіду розвитку освіти та науки у практику вітчизняної діяльності, активізація мобільності здобувачів вищої освіти, розширення можливостей для стажування, навчальних візитів у закордонних університетах, участь співробітників у міжнародних проєктах, розширення договірних зв'язків між навчальними закладами.

Завдяки кооперації проявляються основні ефекти, які цей процес справляє, зокрема на очікування споживачів освітніх послуг, поліпшення процесу надання послуг, на спільні інновації, на організаційні форми взаємодії. Процес надання освітніх послуг в умовах зростаючої глобальної конкуренції сьогодні трансформується завдяки цифровим можливостям, що вимагає нових форм співпраці, а при організації кооперативної взаємодії виникає потреба переглядати форми проведення освітньої діяльності.

Процеси кооперації звичайно матимуть найсуттєвіший вплив на споживача освітньо-наукових послуг. Навчальні заклади стають важливими інституціями у процесах нарощування людського капіталу, а завдяки процесам модернізації освітньої діяльності виникає можливість поліпшення якості життя населення. Завдяки системному підходу, який покладено в основу кооперації, відбувається всебічне врахування очікувань, цілей та завдань, попиту та пропозиції на ринку освітніх послуг, можливостей та потенціалу отримувача послуг, формальних та неформальних засобів навчання.

Суттєвою перевагою кооперації ЗВО вважаємо концентрацію на отримувачі освітньої послуги, тобто перенесення акцентів з пропозиції на попит, на реальні потреби споживача. Крім того, кооперація сприяє тому, що визнаються різні цілі отримання освіти, зокрема персональна підготовка, професійний розвиток, отримання нових знань, досягнення економічних цілей, культурний розвиток, досягнення соціальних ефектів.

Висновки і пропозиції. Однією з найважливіших рис сучасного економічного розвитку, зокрема розвитку освіти, $є$ інтернаціоналізація господарського життя, яка відбувається в умовах глобалізаційних змін та жорсткої конкуренції. Динамізм сучасного життя, виклики глобалізації, нерівномірність розвитку країн та територій призводять до інтеграції національних ЗВО до світового освітнього середовища, поглиблення співпраці у сфері освіти. Точково в Україні запроваджуються кращі практики закордонних університетів та дослідницьких центрів. Проте ці процеси відбуваються безсистемно, немає постійної співпраці між учасниками освітньо-наукової діяльності. 
Саме кооперація вітчизняних закладів вищої освіти з іноземними партнерами в умовах глобальної конкуренції є чинником та драйвером розвитку всіх суб'єктів, як національної, так і світової економіки, які включені прямо або опосередковано в цей процес: здобувачі вищої освіти, заклади вищої освіти, державний сектор, підприємницький сектор, сектор домашніх господарств, світовий та національний ринки освітніх послуг.

Кооперація має за мету сприяння модернізації суспільства в умовах глобалізації, викликів та запитів сучасного світу. Завдяки кооперації виникає можливість у всіх зацікавлених суб'єктів отримати якісно нові компетенції, які необхідні в сучасному світі. Крім того, кооперація стає додатковим чинником нарощування людського потенціалу та його системної капіталізації, що також продукує ефект зростання якості життя. Вбачається за доцільне розширювати наукові розробки в частині дослідження ефектів кооперації для різних груп суб'єктів економічної діяльності, форм кооперації, функціонування та розвитку структур.

\section{Список використаних джерел}

1. Вербицька А. В. Міжнародний ринок освітніх послуг: сучасні тенденції та їх вплив на конкурентоспроможність національної економіки. Управління розвитком. 2018. № 1(191). С. 11-18.

2. Дерій Ж. В. Капіталізація людського потенціалу: теорія, методологія, практика : монографія. Чернігів : ЧНТУ, 2013. 299 с.

3. Дерій Ж. В. Капіталізація людського потенціалу: функціональний аспект. Вісник Черніzівського державного технологічного університету. Серія: Економічні науки. 2012. № 3(60). С. 21-27.

4. Захарін С. В., Коваленко Д. І. Китайсько-українське співробітництво у сфері вищої освіти. Проблеми інтеграчиї освіти, науки та бізнесу в умовах глобалізаџї : матеріали Міжнародної науково-практичної конференції. Київ : Київський національний університет технологій та дизайну, 2019. С. 81-82.

5. Кузьмін О. Є., Яструбський М. Я. Міжнародна кооперація закладів вищої освіти та державне іiі регулювання. Міжнародне науково-технічне співробітництво: принципи, механізми, ефективність : збірник наукових праць XV (XXVII) Міжнародної науково-практичної конференції. Київ, 2019. С. 60-61.

6. Міжнародні наукові проекти. URL: https://mon.gov.ua/ua/tag/mizhnarodni-naukovi-proekti.

7. Розвиток академічного підприємництва в закладах вищої освіти та наукових установах України : круглий стіл (м. Київ, 16 травня 2019) / відп. ред. Д. Ю. Чайка. Київ, 2019. 128 с.

8. Силадій І. М. Розвиток освіти в контексті основних викликів глобалізації. Вища освіта України. 2016. № 4. С. 34-38.

9. Україна на міжнародному ринку освітніх послуг вищої освіти : Аналітична записка / Національний інститут стратегічних досліджень. URL: http://old2.niss.gov.ua/articles/1695/.

10. Холявко Н. І. Модернізація системи вищої освіти в умовах становлення інформаційної економіки : монографія. Чернігів : Видавець Брагинець О. В., 2018. 382 с.

\section{References}

1. Verbytska, A. V. (2018). Mizhnarodnyi rynok osvitnikh posluh: suchasni tendentsii ta yikh vplyv na konkurentospromozhnist natsionalnoi ekonomiky [International market of educational services: current trends and their impact on the competitiveness of the national economy]. Upravlinnia rozvytkom - Development management, 1(191), pp. 11-18.

2. Derii, Zh. V. (2013). Kapitalizatsiia liudskoho potentsialu: teoriia, metodolohiia, praktyka [Capitalization of human potential: theory, methodology, practice]. ChNTU.

3. Derii, Zh. V. (2012). Kapitalizatsiia liudskoho potentsialu: funktsionalnyi aspekt [Capitalization of human potential: functional aspect]. Visnyk Chernihivskoho derzhavnoho tekhnolohichnoho universytetu. Seriia: Ekonomichni nauky - Bulletin of Chernihiv State Technological University. Series: Economic Sciences, 3(60), pp. 21-27.

4. Zakharin, S. V., Kovalenko, D. I. (2019). Kytaisko-ukrainske spivrobitnytstvo u sferi vyshchoi osvity [The Chinese-Ukrainian cooperation in higher education]. Problemy intehratsii osvity, nauky ta biznesu v umovakh hlobalizatsii: materialy Mizhnarodnoi naukovo-praktychnoi konferentsii Problems of integration of education, science and business in the context of globalization: materials of the International scientific-practical conference (pp. 81-82). Kyivskyi natsionalnyi universytet tekhnolohii ta dyzainu. 
ТЕОРЕТИЧНІ ПРОБЛЕМИ РОЗВИТКУ НАЦІОНАЛЬНОЇ ЕКОНОМІКИ

5. Kuzmin, O. Ye., Yastrubskyi, M. Ya. (2019). Mizhnarodna kooperatsiia zakladiv vyshchoi osvity ta derzhavne yii rehuliuvannia [International cooperation of higher education institutions and its state regulation]. Mizhnarodne naukovo-tekhnichne spivrobitnytstvo: pryntsypy, mekhanizmy, efektyvnist : zbirnyk naukovykh prats XV (XXVII) Mizhnarodnoi naukovo-praktychnoi konferentsii International scientific and technical cooperation: principles, mechanisms, efficiency: collection of scientific works of the XV (XXVII) International scientific-practical conference (pp. 60-61).

6. Mizhnarodni naukovi proekty [International research projects] (n.d.). https://mon.gov.ua/ua/tag/ mizhnarodni-naukovi-proekti.

7. Rozvytok akademichnoho pidpryiemnytstva $v$ zakladakh vyshchoi osvity ta naukovykh ustanovakh Ukrainy: kruhlyi stil [Development of academic entrepreneurship higher education institutions and scientific institutions of Ukraine: round table] (2019).

8. Syladii, I. M. (2016). Rozvytok osvity v konteksti osnovnykh vyklykiv hlobalizatsii [Development of education in the context of the main challenges of globalization]. Vyshcha osvita Ukrainy - Higher education in Ukraine, (4), pp. 34-38.

9. Natsionalnyi instytut stratehichnykh doslidzhen [National Institute for Strategic Studies]. Ukraina na mizhnarodnomu rynku osvitnikh posluh vyshchoi osvity: Analitychna zapyska [Ukraine in the international market of educational services of higher education: Analytical note]. http://old2.niss.gov.ua/articles/1695/.

10. Kholiavko, N. I. (2018). Modernizatsiia systemy vyshchoi osvity v umovakh stanovlennia informatsiinoi ekonomiky [Modernization of higher education in the formation of the information economy]. Vydavets Brahynets O. V.

Бебко Світлана Вікторівна - кандидат економічних наук, доцент, доцент кафедри ділової іноземної мови

та міжнародної комунікації, Національний університет харчових технологій (вул. Володимирська, 68, м. Київ, 01601, Україна).

Бебко Светлана Викторовна - кандидат экономических наук, доцент, доцент кафедры делового иностранного языка и международной коммуникации, Национальный университет пищевых технологий (ул. Владимирская, 68, г. Киев, 01601, Украина).

Bebko Svitlana - PhD in Economic Sciences, Associate Professor, Associate Professor of Business Foreign Language and International Communication Department, National University of Food Technologies (68 Volodymyrska Str., 01601 Kyiv, Ukraine).

E-mail: sried@mail.ua

ORCID: https://orcid.org/0000-0002-0687-3801 